\title{
PELAKSANAAN ATRAUMATIC CARE DI RUMAH SAKIT
}

\section{IMPLEMENTATION OF ATRAUMATIC CARE IN HOSPITAL}

\author{
Lisdiyanti Usman \\ Politeknik Kesehatan Kemenkes Gorontalo \\ Kontak Penulis: usmanlisdiyanti@gmail.com
}

\begin{abstract}
ABSTRAK
Pemberian asuhan keperawatan kepada klien anak, seorang perawat harus memahami bahwa semua asuhan keperawatan anak harus berpusat pada keluarga (family center care) untuk mencegah terjadinya trauma (atraumatik care). Atraumatic care adalah penyediaan asuhan terapeutik melalui penggunaan intervensi yang memperkecil stres psikologis dan fisik yang diderita oleh anak dan keluarganya dalam sistem pelayanan kesehatan. Atraumatic care merupakan suatu tindakan terapeutik. Ketika anak sakit dan dianjurkan untuk dirawat di rumah sakit, anak tidak pernah terlepas dari dampak negatif hospitalisasi. Oleh karenanya perawat berusaha menerapkan prinsip atraumatic care dalam memberikan asuhan keperawatan kepada anak maupun keluarganya, seperti: melibatkan orang tua dalam setiap tindakan atau implementasi yang akan dilakukan untuk kesembuhan sang buah hati, membolehkan anak membawa boneka atau robot kesayangan selama perawatan. Keluarga menyerahkan segala keputusan untuk keselamatan anaknya kepada petugas kesehatan, oleh karena itu untuk menghindari terjadinya dampak negatif hospitalisasi pada anak, maka diharapkan komunikasi antara orang tua dan petugas kesehatan selalu berkesinambungan. Penerapan atraumatic care dapat meminimalisir terjadinya stres pada anak maupun keluarga.
\end{abstract}

Kata kunci: kendala; atraumatic care

\begin{abstract}
Providing nursing care to the child's client, a nurse must understand that all child nursing care must be family centered to prevent trauma (atraumatic care). Atraumatic care is the provision of therapeutic care through the use of interventions that minimize psychological and physical stress suffered by children and their families in the health care system. Atraumatic care is a therapeutic action. When a child is sick and recommended to be treated in a hospital, the child is never separated from the negative effects of hospitalization. Therefore nurses try to apply the principle of atraumatic care in providing nursing care to children and their families, such as: involving parents in every action or implementation that will be performed to cure the baby, allowing children to bring their favorite doll or robot during treatment. Families submit all decisions for the safety of their children to health workers, therefore to avoid the negative impact of hospitalization on children, it is expected that communication between parents and health workers is always continuous. The application of atraumatic care can minimize stress on children and families.
\end{abstract}

Keywords: obstacles; atraumatic care 


\section{PENDAHULUAN}

Hospitalisasi dapat menyebabkan anak mengalami trauma dan menimbulkan gejala berupa respon gelisah, cemas, apatis, ketakutan terhadap perpisahan dengan orang tua, apatis, dan terjadi gangguan tidur (Rahmah \& Agustina, 2015). Anak-anak yang menjalani hospitalisasi di Indonesia diperkirakan 35 per 1000 anak (Purwandari dalam Rini., et al 2013). Dampak negatif ini berkaitan dengan lama dan banyaknya jumlah klien anak, berbagai prosedur tindakan invasif, serta kecemasan orangtua. Tindakan yang dilakukan dalam mengatasi masalah anak apapun bentuknya harus berlandaskan pada prinsip atraumatic care atau asuhan yang terapeutik.

Pelayanan atraumatic care merupakan bentuk pelayanan perawatan terapeutik dalam tatanan pelayanan kesehatan anak melalui penggunaan tindakan yang mengurangi distres fisik maupun distres psikologis yang dialami anak maupun orang tua (Supartini, 2004). Menurut Hidayat (2005), ada beberapa prinsip perawatan atraumatic care yang harus dimiliki oleh perawat anak yaitu menurunkan atau mencegah dampak perpisahan dari keluarga, meningkatkan kemampuan orang tua dalam mengontrol perawatan anak, mencegah atau mengurangi cedera (injury) dan nyeri (dampak psikologis), tidak melakukan kekerasan pada anak, dan modifikasi lingkungan fisik. Semakin baik penerapan Atraumatic care yang diberikan maka semakin kecil risiko kecemasan yang dialami anak prasekolah saat proses hospitalisasi (Maghfuroh, 206).

\section{Kolaborasi Orang Tua dan Tenaga Professional}

Kolaborasi orangtua dan tenaga profesional dalam membentuk mendukung keluarga terutama dalam aturan perawatan yang mereka lakukan merupakan filosofi Family Centered Care. Family Centered Care merupakan hal penting dalam hospitalisasi anak yang mengharuskan anak untuk tinggal dan dirawat di Rumah Sakit dan harus menjalani perawatan sampai pemulangannya kembali kerumah (Tanaem., et al, 2019). Kemudian, secara lebih sfesifik dijelaskan bahwa filosofi Family Center Care yang dimaksudkan merupakan dasar pemikiran dalam keperawatan anak yang digunakan untuk memberikan asuhan keperawatan kepada anak dengan melibatkan keluarga sebagai fokus utama perawatan. Kutipan definisi dari para ahli diatas memberikan bahwa dalam penerapan Family Centered Care sebagai suatu pendekatan holistik dan filosofi dalam keperawatan anak.

Perawat sebagai tenaga profesional perlu melibatkan orang tua dalam perawatan anak. yaitu asuhan yang tidak menimbulkan trauma pada anak dan keluarga, yang merupakan asuhan terapeutik karena bertujuan sebagai terapi bagi anak. Prinsip utama dalam asuhan terapeutik adalah mencegah atau menurunkan dampak perpisahan antara orang tua dan anak dengan menggunakan pendekatan family centered. Tingkatkan kemampuan orang tua dalam mengontrol perawatan anaknya. Mencegah dan menurunkan cedera baik fisik maupun psikologis.

\section{Melakukan Modifikasi Lingkungan Rumah Sakit}

Atraumatic care adalah perawatan yang tidak menimbulkan trauma pada anak dan keluarga. Atraumatik care sebagai bentuk perawatan terapeutik dapat diberikan kepada anak dan keluarga dengan mengurangi dampak psikologis dari tindakan keperawatan yang diberikan, seperti memperhatikan dampak psikologis dari tindakan keperawatan yang diberikan dengan melihat prosedur tindakan atau aspek lain yang kemungkinan berdampak adanya trauma. Tindakan yang dilakukan dalam mengatasi masalah anak apapun bentuknya harus berlandaskan pada prinsip atraumatic care atau asuhan yang terapeutik (Breving, et al, 2015). Menurut Ulfa, et al (2015) pelaksanaan atraumatic care oleh perawat yang dilaksanakan dengan baik dapat menurunkan atau 
mencegah munculnya stres pada orangtua dan anak. Pencapaian perawatan tersebut beberapa prinsip yang dapat dilakukan oleh perawat antara lain:

1. Menurunkan atau mencegah dampak perpisahan dari keluarga

Dampak perpisahan dari keluarga akan menyebabkan kecemasan pada anak sehingga menghambat proses penyembuhan dan dapat mengganggu pertumbuhan dan perkembangan anak.

2. Meningkatkan kemampuan orang tua dalam mengontrol perawatan pada anak.

Kemampuan orang tua dalam mengontrol perawatan pada anak dapat meningkatkan kemandirian anak dan anak akan bersikap waspada dalam segala hal.

3. Mencegah atau mengurangi cedera (injury) dan nyeri (dampak psikologis)

Proses pengurangan rasa nyeri sering tidak bisa dihilangkan secara cepat akan tetapi dapat dikurangi melalui berbagai tekh.nik misalnya distraksi, relaksasi dan imaginary. Apabila tindakan pencegahan tidak dilakukan maka cedera dan nyeri akan berlangsung lama pada anak sehingga dapat mengganggu pertumbuhan dan perkembangan anak.

4. Tidak melakukan kekerasan pada anak.

Kekerasan pada anak akan menimbulkan gangguan psikologis yang sangat berarti dalam kehidupan anak, yang dapat menghambat proses kematangan dan tumbuh kembang anak.

5. Modifikasi lingkungan.

Melalui modifikasi lingkungan yang bernuansa anak dapat meningkatkan keceriaan dan nyaman bagi lingkungan anak sehingga anak selalu berkembang dan merasa nyaman dilingkungan.

\section{Peran Perawat dalam Perawatan Anak}

Perawat pediatrik bertanggung jawab untuk memberikan penyuluhan kesehatan kepada anak dan keluarga. Menurut Wulandari (2011) prinsip perawatan atraumatik yang harus dimiliki oleh perawat anak dalam merawat pasien anak yaitu diantaranya adalah mencegah atau meminimalkan stressor fisik dan psikis yang meliputi prosedur yang menyakitkan seperti suntikan, kegelisahan, ketidakberdayaan, tidur yang tidak nyaman, pengekangan, suara bising, bau yang tidak sedap dan lain-lain, mencegah dampak perpisahan orang tua dan anggota keluarga yang lain, bersikap empati keluarga dan anak yang sedang dirawat serta memberikan pendidikan kesehatan tentang kondisi sakit yang dialami anak. Adanya hubungan terapeutik antara perawat, klien dan keluarga merupakan dasar untuk memberikan asuhan keperawatan yang berkualitas. Dengan komunikasi antara perawat dan keluarga diharapkan dapat mempercepat proses penyembuhan klien. Perawat membantu klien dan keluarga dalam membuat suatu keputusan atau pilihan informasi dalam bertindak untuk kepentingan anak. Adanya pendekatan perawat memastikan bahwa keluarga menyadari semua pelayanan kesehatan yang tersedia, tindakan medis maupun non medis yang sesuai standar operasional prosedur memerlukan kerja sama dengan melibatkan keluarga. Sebagai perawat pediatrik, perawat harus dapat menunjukkan peduli, kasih sayang, dan empati terhadap orang lain. Perduli diwujudkan dengan mengetahui konsep perawatan attraumatic dan pengembangan dari hubungan terapeutik antara klien, keluarga dan perawat. Keluarga menggambarkan pribadi seseorang yang begitu takut, cemas, gelisah ketika mendengar anaknya harus dirawat di rumah sakit.

Adapun peran perawat sebagai perawat anak diantaranya :

1. Sebagai Pemberi perawatan

2. Sebagai Advokad keluarga

3. Sebagai pendidik 


\section{Konseling \\ 5. Kolaborasi \\ 6. Peneliti}

\section{Kendala yang Dihadapi Perawat Anak}

Perawat anak adalah bagian dari tim keperawatan yang menjunjung tinggi prinsip keperawatan anak dengan disiplin ilmu kesehatan yang berfokus pada kesejahteraan anak. Dikatakan sejahtera jika anak tidak merasakan ganggguan psikologis, seperti rasa cemas, takut atau lainnya, dimana upaya ini tidak terlepas juga dari peran keluarga. Melalui modifikasi lingkungan yang bernuansa anak dapat meningkatkan keceriaan dan kenyamanan bagi lingkungan anak sehingga anak selalu berkembang dan merasa nyaman dilingkungannya.

Ada beberapa kendala yang sering dihadapi perawat anak diantaranya adalah:

1. Kurangnya kerjasama

Sebagai seorang perawat khususnya perawat anak, memang tidaklah mudah oleh karena kerjasama tim sangat menentukan semuanya. Sulit bagi perawat anak untuk bekerja dalam lingkungan dimana tidak ada kerjasama tim kesehatan lainnya dan juga kerjasama dengan keluarga klien. Karena tidak sedikit keluarga yang capek mengurus anaknya kemudian dilampiaskan ke perawat dengan marah marah hanya karena selang infuse anaknya keluar darah Orang tua dan keluarga tidak mampu mendukung perawat dalam pelaksanaan atraumatic care yang ditunjukkan dengan sikap orang tua dan keluarga yang tidak percaya terhadap perawat, menangis, dan menyalahkan perawat (Apriyani., et al, 2014).

2. Paparan terhadap resiko infeksi tinggi

Dibanding dengan perawat di ruangan lain, perawat anak cenderung memiliki resiko infeksi lebih tinggi oleh karena berhadapan dengan klien itu sendiri dan orang tua atau keluarga klien tersebut.

3. Fasilitas mainan anak di Rumah Sakit masih kurang

Dunia anak adalah dunia bermain, melalui bermain aspek perkembangan anak ditumbuhkan sehingga dapat merangsang anak berpikir walaupun dalam keadaan sakit. Karakteristik anak-anak berbeda-beda untuk masing-masing usia, oleh karena itu kesabaran perawat anak menentukan keberhasilan intervensi yang telah direncanakan. Salah satu fasilitas yang harus disediakan oleh pihak rumah sakit yaitu tempat bermain untuk melaksanakan terapi bermain pada klien anak tersebut.

\section{REFERENSI}

Apriani, L., Kasmirah., Yulianti, N, R. (2014). Hambatan Perawat Anak dalam Pelaksanaan Atraumatic Care di Rumah Sakit di Kota Salatiga. Jurnal Keperawatan Anak. Fakultas Ilmu Keperawatan dan Kesehatan Universitas Muhammadiyah Semarang, https://jurnal.unimus.ac.id/index.php/JKA/article/view/3969/3686

Breaving, R, M., Ismanto, A, Y., Onibala, F. (2015). Pengaruh Penerapan Atraumatic Care Terhadap Respon Kecemasan Anak Yang Mengalami Hospitalisasi di RSU Pancaran Kasih GMIM Manado dan RSUP Prof. Dr. R. D. Kandou Manado. E Journal Keperawatan (e$K p), 3(2) .1-9$

Hidayat, A. A. (2005). Pengantar Ilmu Keperawatan Anak. Jakarta: Selemba Medika.

Maghfuroh, L. (2016). Atraumatic Care Menurunkan Kecemasan Hospitalisasi pada Anak Prasekolah di Ruang Anggrek RSU Dr. Soegiri Lamongan. Jurnal SURYA, 8(1). 40-45 
Rahmah, S., \& Agustina, F. (2015). Hubungan Penerapan Atraumatic Care dengan Stres Hospitalisasi pada Anak di Ruang Anak Rumah Sakit Umum Cut Meutia Kabupaten Aceh Utara Tahun 2015. Jurnal Kesehatan Almuslim, 1(2). 11-17

Rini, D, M., Sari, R., \& Rahmawati, I. (2013). Hubungan Penerapan Atraumatic Care dengan Kecemasan Anak Prasekolah Saat Proses Hospitalisasi di RSU dr. H. Koesnadi Kabupaten Bondowoso. Artikel Ilmiah Hasil Penelitian Mahasiswa 2013. Program Studi Ilmu Keperawatan, Universitas Jember (UNEJ). https://repository.unej.ac.id

Supartini, Y. (2004). Buku Ajar Konsep Dasar Keperawatan Anak. Jakarta: EGC.

Tanaem, G, H., Dary., \& Istiarti, E. (2019). Family Centered Care pada Perawatan Anak di RSUD SOE Timor Tengah Selatan. Jurnal Riset Kesehatan, 8(1). 21-27. DOI: 10.31983/jrk.v8i1.3918

Ulfa, F, M., Oktavianto, E., Zuleha, R. (2015). Hubungan Penerapan Atraumatic Care oleh Perawat dengan Stres Orangtua Selama Hospitalisasi Bayi. Health Sciences and Pharmacy Journal, 2(3). 82-88

Wulandari, R. (2011). Peran Perawat Anak terhadap Prinsip Perawatan Atraumatik pada Anak. Jurnal GASTER, 8(1). 1-11 